İş ve İnsan Dergisi | The Journal of Human and Work

Y1l | Year: Ekim | October 2020

Cilt-Say1 | Volume-Issue: 7 (2)

ss I pp: 213-227

doi: 10.18394/iid.746740

e-ISSN 2148-967X

http://dergipark.gov.tr/iid/

Research Article

\title{
İş Yükünün İşten Ayrılma Niyeti Üzerine Etkisinde İş Tatmini ve Kişi- Örgüt Uyumunun Aracılık Rolü
}

\author{
The Effect of Overload on the Turnover Intent on the Role of Job Sattsfaction and \\ Person-Organization Fit:
}

Adnan Eroğlua

\section{MAKALE BİLGİII}

Anahtar Kelimeler:

Aşırı İş Yükü, İş Tatmini,

Isten Ayrllma Niyeti,

Kişi-Örgüt Uyumu

Tarihler:

Gelis 1 Haziran 2020

Kabul 16 Temmuz 2020

\section{ARTICLE INFO}

\section{Keywords:}

Work Load, Job Satisfaction,

Turnover Intent,

Person-Organization Fit

Article history:

Received 1 June 2020

Accepted 16 July 2020

\begin{abstract}
ÖZ
Çalı̧̧ma, iş görenlerin aşırı iş yükü ve işten ayrılma niyeti ilişkisi üzerinde iş tatmini ve kişiörgüt uyumu etkilerini inceleyen bütüncül bir model sunmaktadır. Araștırmanın örneklemini, ulusal düzeyde güvenlikten sorumlu kamu kuruluşunun Kayseri ve Bolu illerinde görevli 581 sözleșmeli çalıșanı olușturmaktadır. Araștırma verileri anket tekniği kullanılarak toplanmıștır. Araştırma değişkenlerinin ölçülmesinde Aşırı İş Yükü, Iş Tatmini, Kişi-Örgüt Uyumu ve İşten Ayrılma Niyeti ölçekleri kullanılmıștır. Ölçeklerin geçerlilikleri doğrulayıcı faktör analizi ile test edilmiştir. Değişkenler arasındaki iliş̧kiyi belirlemek için korelasyon ve hiyerarşik regresyon analizinden, aracılık testleri için SPSS 15 programı üzerinde çalıșan PROCESS v3.0 eklentisinden yararlanılmıştır. Elde edilen bulgular çalışanların aşırı iş yükü algılarının işten ayrllma niyetini anlamll ve aksi yönde etkilediğini göstermektedir. Așlrı iş yükü ve ișten ayrlma niyeti ilişsisi üzerinde hem iş tatmininin hem de kişi-örgüt uyumunun aracllık rolü olduğu tespit edilmiștir. Sonuç olarak değișkenler arası ilișkiler araștırma modeli çerçevesinde genel olarak desteklenmiş, araştırmanın yazına katkısı ve gelecekteki araştırmalara yönelik öneriler sunulmuştur.
\end{abstract}

\begin{abstract}
A B S T R A C T
The study provides a holistic model that examines the effects of job satisfaction and personorganization fit on the relationship of the worker's work overload and intention to quit. The sample of the study consists of 581 contract employees working in Kayseri and Bolu provinces of the public institution responsible for security at national level. The research data were collected using the survey technique. In measuring the variables of the research, work overload, job satisfaction, person-organization fit and intention to quit scales were used. Validity of the scales was tested by confirmatory factor analysis. Correlation and hierarchical regression analysis were used to determine the relationship between variables, for mediation tests PROCESS v3.0 used which is running on SPSS 15. The findings show that employees' perceptions of work overload significantly and negatively affect their intention to quit. It was determined that both job satisfaction and person-organization fit play a mediation role on the relationship between work overload and intention to quit. As a result, the relationships between variables were generally supported within the framework of the research model, the contribution of the research to the literature and suggestions for future research were presented.
\end{abstract}

\footnotetext{
a Corresponding author, Doktora Ögrencisi, Ankara Yıldırım Beyazıd Üniversitesi, Sosyal Bilimler Enstitiüsü, İsletme, Yönetim ve Organizasyon Ana Bilim Dall, Türkiye.E-mail: aeroglu1996@gmail.com.ORCID: 0000-0003-0952-9114.
} 


\section{GíRiş}

Çalışanların işten ayrılma davranışı, 20 yıldan daha uzun süredir araştırmaların odağında olup, araştırmacılar işten ayrılma sürecini anlamaya dönük birçok modeli test etmektedir (Griffeth, Hom, \& Gaertner, 2000; Hom \& Griffeth, 1991). $\mathrm{Bu}$ büyük ilginin nedeni, işten ayrılmanın genellikle örgütsel etkililiğin olumsuz bir indeksi olarak düşünülmesidir (Alexander, Bloom, \& Nuchols, 1994; Dalton, Todor, \& Krackhardt, 1982). Çalışanların örgütte kalma konusundaki isteksizliği, beklentilerinin büyük ölçüde karşılanmamış olmasıyla açıklanmaktadır (Porter \& Steers, 1973).

İşten ayrılma, bir çalışanın gönüllü ya da gönülsüz olarak sürekli bir şekilde örgütten uzaklaşmasını ifade ederken (Koslowsky, Sagie, Krausz, \& Singer, 1997), işten ayrılma niyeti ise çalışanın karşısına daha iyi bir iş firsatı çıktığında işten ayrılma eğilimini ifade etmektedir. İşten ayrılma eğiliminin, işten ayrılma davranışının önemli bir yordayıcısı olduğunu ortaya koyan çalışmalar (Mobley, 1977; Morrell, Loan-Clarke, \& Wilkinson, 2001; Sümer \& Van de Ven, 2007) bulunmaktadır.

İnsan kaynakları herhangi bir örgütün en hayati ve dinamik kaynaklarıdır. Günümüzde örgütlerin karşılaştığı en büyük zorluk sadece bu kaynakları yönetmek değil aynı zamanda bunları muhafaza etmektir. Vasıflı çalışanların güvence altına alınması ve elde tutulması her örgüt için önemli bir rol oynamaktadır çünkü çalışan bilgi ve becerileri örgütün ekonomik rekabet yeteneğinin merkezinde yer almaktadır (Das \& Baruah, 2013).

Çalışanların gönüllü, kendi istekleri ile örgütten ayrılmaları, örgütler için ciddi şekilde maliyetli olmaktadır. İşten ayrılma sadece personel istihdam maliyetini artırmamakta, aynı zamanda örgütsel bilgi sermayesinin azalmasına ve örgütün prestijinin zayıflamasına sebep olabilmektedir (Shaw, Gupta \& Delery, 2005). Bu nedenledir ki etkili bir personeli elde tutma politikası oluşturmak ve örgütsel etkililiği artırmak açısından çalışanların kendi istekleri ile örgütten ayrilma sürecini anlamak önemlidir (Griffeth vd., 2000).

İşten ayrılma niyeti ile ilgili araştırmalar incelendiğinde konunun bir bütünlük içerisinde ele alınmaktan çok her bir değişkenin doğrudan etkilerine odaklanılıp dolaylı etkilerinin kısmen göz ardı edildiği görülmüştür. Ayrıca ulusal yazında aşırı iş yükü ile işten ayrılma eğilimi arasındaki nedensellik ilişkisine yönelik araştırmaların sınırlı kaldığı gözlenmiştir. Çalışma, bu boşluğu doldurmak maksadıyla işten ayrılma niyetini etkilediği düşünülen bireysel, işsel ve örgütsel düzeydeki değişkenlerin ilişkilerini bütüncül bir model içerisinde sunmaktadır.

Çalışmanın temel olarak iki amacı bulunmaktadır. Birinci amacı, literatürdeki kuramsal ilişkilerden hareketle işten ayrılma niyetini anlamaya yönelik olarak bütüncül bir model kurmak ve bu modeli ulusal düzeyde güvenlikten sorumlu bir örgütte test etmektir. Bu maksatla aşırı iş yükünün işten ayrılma niyeti üzerindeki doğrudan ve dolaylı etkileri öngörülen bütüncül model çerçevesinde tartışılacaktır.

İkinci amacı ise ülke güvenliğinden sorumlu bir örgüt özelinde işten ayrılma eğiliminin tetikleyicilerini tanımlayarak bu dinamiklerin nasıl çalıştığını ortaya çıkarmaktır. Böylece hem kuramsal katkılar sağlanması, hem de ülke güvenliği açısından kritik önemdeki güvenlik personelinin örgütte kalmasını kolaylaştırmaya yönelik öneriler getirilmesi hedeflenmektedir.

Çalışmanın bir sonraki bölümünde işten ayrılma niyeti, aşırı iş yükü, iş tatmini ve kişi-örgüt uyumuna ilişkin kavramsal çerçeveye değinilmiş ve araştırma hipotezleri sunulmuştur. Bundan sonraki bölümlerde ise sırasıyla yöntem, bulgular, tartışma ve sonuç kısımları yer almıştır.

\section{KAVRAMSAL ÇERÇEVE}

\section{1. İşten Ayrılma Niyeti}

Çalışanın beceri kazanımının büyük bir yatırımı temsil ettiği giderek karmaşıklaşan dünyada, kalifiye personeli elde tutma stratejilerini geliştirme ihtiyac1, örgütün temel yetkinliğinin risk altında olduğu herhangi bir alanda strateji geliştirmekten daha az önemli değildir (Steel, Griffeth \& Hom, 2002). Modern örgütlerin çoğunda, uzmanlık becerisine sahip çalışanların elde tutulması son zamanlarda stratejik bir öncelik olarak ortaya çıkmaktadır (Van Dyk \& Coetzee, 2012).

Fishbein ve Ajzen (1975) tarafindan bireyin sergilediği davranışın başlıca belirleyicisinin söz konusu davranışı gerçekleştirme eğilimi ölçüsü olacağ1 ifade edilmektedir (Fishbein \& Ajzen, 1975'den aktaran Yücel, 2012). Bu nedenle çalışanların işten ayrılma davranışı yerine işten ayrılma niyetini yordayan faktörler belirlenebilirse, bu niyetin hayata geçirilmesinin önüne geçilebilir ve böylece hem örgüt hem de çalışan için birtakım yatırımlar uzun vadede her iki taraf için de kazanca dönüştürülebilir (Yücel \& Demirel, 2013). 
İșten ayrılma niyeti hakkında birçok tanımdan bahsedilebilir. İşten ayrılma davranışı hemen öncesinde işten ayrılma davranışsal niyeti (Mowday, Koberg \& McArthur, 1984); tutumsal bir yönelimi veya davranışsal ayrılma kararının bilişsel bir tezahürü (Elangovan, 2001); çalışanın belirli bir süre içinde işini değiştirme olasılığı (Sousa-Poza \& Henneberger, 2004); bilinçli ve maksatlı örgütten ayrılma isteği (Tett \& Meyer, 1993); bireyin yakın gelecekte bir örgütten ayrılma olasılığına ilişkin sübjektif tahmini (Mowday, Porter \& Steers, 1982); yakın gelecekte bir örgütü terk etmek için bilinçli ve kasitlı bir arzu (Mobley, Horner \& Hollingsworth, 1978); bireyin çalıştığ kalma veya ayrılma olasılığı (Cotton \& Tuttle, 1986) bu tanımlamalardan bazılarıdır.

Çok sayıda araştırmacı (Bluedorn, 1982; Kalliath \& Beck, 2001; Peters, Bhagat \& O'Connor, 1981; Saks, 1996) işten ayrılma niyetinin muhtemel öncüllerini çalışmak suretiyle bireyin işten ayrılma eğilimini neyin belirlediği sorusuna cevap vermeye çalışmıştır. Nitekim Firth, Mellor, Moore ve Loquet (2004), eğilimlerin sonraki davranışın doğru bir göstergesi olduğunu iddia etmek makul olsa da halen bu tür eğilimleri neyin belirlediğinin araştırılmaya muhtaç olduğunu savunmaktadır (Firth, Mellor, Moore \& Loquet 2004). İşten ayrılma niyetinin önemli belirleyicilerinden biri de aşırı iş yüküdür (Brannon, Barry, Kemper, Schreiner \& Vasey, 2007).

\subsection{Așırı İş Yükü}

Bireyin örgütsel rolü ile ilgili belli bir zaman diliminde ve standartta yapılması gerekli iş miktarı olarak tanımlayabileceğimiz (Maslach \& Leiter, 1997) iş yükü, çalışma yaşamının temel yapı taşlarından birisi olarak karşımıza çıkmaktadır. Aşırı iş yükü, çalışanların sınırlarını aşan iş gereklilikleri yani çok fazla miktarda işin belirlenen süre içerisinde tamamlanması gerekliliği veya çalışma süresinin çok uzun olması halinde çalışanın buna fiziksel veya ruhsal olarak dayanamaması şeklinde ifade edilebilir (Xiaoming, Ma, Chang \& Shieh, 2014).

Yazında aşırı iş yükü hem nicel hem de nitel terimlerle tanımlanabilmektedir (Greenhaus, Parasuraman, Granrose, Rabinowitz, \& Beutell, 1989). Beehr, Walsh ve Taber (1976) nicel iş yükünü, fiziksel olarak çok fazla işin verilen süre içerisinde yapılması olarak görürken, Sverke, Hellgren ve Öhrming (1999) ise nitel iş yükünü, bireyin örgüt içinde sahip olması gereken beceri, yetenek veya bilgi olarak tanımlayabilmektedir (Beehr vd., 1976; Sverke vd., 1999'dan aktaran Pienaar, Sieberhagen \& Mostert, 2007).
Aşırı iş yükü düşük heyecana, işi geciktirmeye, düşük takım atmosferine ve sonrasında örgütsel performansı etkileyecek kurallara uyulmamasina yol açabilir (Colucia \& Alexandrea, 2012). Ağır iş yükünün çoğu kez düşük iş tatmini, duygusal tükenme ve stres belirtileri ile ilişkili olduğunu gösteren çalışmalar bulunmaktadır (Cordes \& Dougherty, 1993; Landsbergis, 1988; Repetti, 1993; Spector, Dwyer \& Jex, 1988). Öyle ki Zeytinoğlu vd. (2007) tarafindan hemşireler üzerinde yapılan çalışmada, tüm hemşireler için artan iş yükü ile iş tatmini anlamlı ve aksi yönde ilişkiliyken, işten ayrılma niyetiyle anlamlı ve aynı yönde ilişkili olduğu sonucuna ulaşılmıştır (Zeytinoğlu vd., 2007).

Aşırı iş yükü çalışanın bir iși layıkıyla ve zamanında tamamlama becerisi hakkında belirsizliğe yol açabilir (Spector \& Jex, 1998). Bu nedenle çalışanı meşgul edecek, tatmin duygusu yaratacak ve örgüte bağlı kılacak, ancak şevkini kıracak kadar da çok olmamak üzere teorik olarak optimum seviyede bir iş yükü var olmalıdır (Pienaar vd., 2007). Nitekim Coverman (1989), iş yükündeki bir azalmanın iş tatmininde bir artışla ilişkili olabileceğini öne sürmektedir (Coverman, 1989).

\section{3. İş Tatmini}

Moorman, Niehoff ve Organ (1993) iş tatmininin anlamını resmeden üç pratik bakış açısı bulunmaktadır: Bunlar, toplumun değerli bir yap1 öğesi, bir örgüt için erken aşamada erken uyarı göstergesi ve son olarak örgütsel davranışın bir belirleyicisi işlevini görüyor olmasıdır. Brookfield (1998) ise örgütteki çalışanların yeteneklerini çekmek ve sürdürmek için iş tatmininin kritik bir rol oynadığını ifade etmektedir. Brookfield'e (1998) göre yüksek düzeyde iş tatmini olan bireyler, iş performansında yüksek verimlilik ve etkinlik sağlayacak, örgütte daha uzun süre kalmak suretiyle sağlıklı fiziksel ve ruhsal sicillere sahip olabilecektir (Moorman, Niehoff \& Organ, 1993; Brookfield, 1998'den aktaran Samad, 2006).

İş tatmini, bireyin işinden elde ettiği memnuniyet (Hackman \& Oldham, 1974), bireylerin işlerini algılayışlarının bir sonucu olarak sahip oldukları bir tutum (Ivancevich \& Matteson, 1987), bireyin iş tecrübelerinden veya örgüte olan uyumundan kaynaklanan hoşa giden bir tutum veya haz veren duygusal bir durum (O'Reilly, Chatman \& Caldwell, 1991) veya çalışanın gerçekte ne aldığından ziyade ne almak istediğinin farklı algılamalarına verilen bilişsel ve duygusal tepkilerin birleşimi olarak tanımlanabilir (Hellman, 1997).

Örgütsel, mesleki ve kişisel değişkenler ile ilişkili literatürde iş tatminini, işten ayrılmada anahtar bir 
faktör olarak tanımlamak mümkün olabilmektedir (Lu, Alison, While, \& Barriball, 2005). Ivancevich ve Matteson (1987) işverenlerin memnuniyetsiz çalışanlardan ziyade memnun çalışanları tercih ettiğini ifade etmektedir (Ivancevich \& Matteson, 1987). Çalışanların örgütte muhafaza edilmesi ve iş verimliliği doğrudan çalışan tatmini ile ilgilidir (Yadav \& Aspal, 2014). Nitekim çalışanlar ne kadar memnuniyetsiz ise diğer iş fırsatlarını dikkate alma olasılıkları o kadar yüksektir (Hellman, 1997).

İş tatmininin öncüllerinden biri olan aşırı iş yükünün iş tatminini aksi yönde ve anlamlı bir şekilde etkilediği (Zeytinoğlu vd., 2007), iş tatmininin de işten ayrılma niyetini aksi yönde ve anlamlı bir şekilde etkilediği (Price \& Mueller, 1981; Shore \& Martin, 1989; Aryee, Wyatt \& Min, 1991; Chan \& Morrison, 2000; Ghiselli, Lopa, \& Bai, 2001; McBey \& Karakowsky, 2001; Lam, Zhang \& Baum, 2001; Amah, 2009) çalışmalar bulunmaktadır. İş tatmininin ilişkili olduğu değişkenlerden biri de birey ile örgüt değerlerinin uyumunu temsil eden kişi-örgüt uyumudur (Boxx, Odom, \& Dunn, 1991; Vancouver \& Schmitt, 1991; Bretz \& Judge, 1994; Kristof-Brown, 1996; Silverthorne, 2004; Sims \& Kroeck, 1994).

\subsection{Kişi-Örgüt Uyumu}

Kişi-örgüt uyumu, bireyin değerlerinin örgütsel bağlam içerisindeki değer sistemi ile yan yana koyulduğunda, bireyin tutum ve davranışlarını ne şekilde ve kapsamda etkilediğine odaklanmaktadır (Chatman, 1991). Çalışanlar değerleri, örgüte katılımlarını da içeren seçimleri yapmak için kullanırken örgütler ise değerleri kabul edilebilir çalışan inanışları ve davranışlarına rehber olabilecek bir kültür inşa etmek için kullanır (Westerman \& Cyr, 2004).

Kişi-örgüt uyumu, bireysel değerler ve örgütsel değerler arasındaki ahenk veya eşleşme şeklinde tanımlanmaktadır (Adkins, Russell, \& Werbel, 1994; Judge \& Bretz, 1992; Judge \& Ferris, 1992). Chatman (1989), kişi-örgüt uyumunu örgütün norm ve değerleri ile bireyin değerleri arasındaki uyum olarak ifade etmektedir. $\mathrm{Bu}$ tanım kişi ve örgüt arasındaki değer temelli uyuma işaret etmektedir (Chatman, 1989'dan aktaran Alnıaçık, Alnıaçık, Erat, \& Akçin, 2013).

Kişi-Örgüt uyumu üzerine araştırmalar, esas itibariyle kişiler ve çalıştıkları örgütler arasındaki uyumun öncülleri ve sonuçları ile ilgilenmektedir. Bireyi işe alma ve örgüte kazandırma sürecinde yüksek seviyede kişi-örgüt uyumuna erişilmesi, rekabetçi zorlukların üstesinden gelinmesinde esnek ve örgütsel bağlılığı olan iş gücünü örgütte tutmada kilit rol oynamaktadır (Kristof-Brown, 1996). Zira daha düşük değer uyumu olan çalışanlar, yüksek uyum sergileyenlere nazaran daha çok örgütten ayrılma eğilimi rapor etmektedir (O'Reilly vd., 1991; Chatman, 1991).

\subsection{Araştırma Değişkenleri Arasındaki İlişkiler}

Araştırma değişkenleri arasındaki ilişkiler İş Talepleri-Kaynakları Kuramına dayanmaktadır. Bu modele göre yüksek iş talepleri muhtemelen stres, tükenmişlik gibi zorlu tepkimelere yol açabilir, bu da devamsızlık ve işten ayrılmada artışa neden olabilir. Bu kuramdan yola çıkarak çalışanların iş yükü arttığında işe duyulan hazzın azalması ve kişi ve örgüt arasındaki değer uyumunun zayıflaması, buna bağlı olarak işten ayrılma eğiliminin artması beklenmektedir.

Aşırı iş yükü ve işten ayrılma niyeti. Çalışanların ağır iş yükü algılamaları, onların işe yönelik tutumlarını etkilemek suretiyle bireyin sağlığını, performansını ve verimini etkileyebilmekte, bunun sonucunda daha fazla işten ayrılmaya niyetlenmektedir (Zeytinoğlu vd., 2007). Bu kapsamda aşağıdaki araştırma hipotezi geliştirilmiştir.

Hipotez 1: Aşırı iş yükü algllarının işten ayrılma niyeti üzerinde anlamll etkisi vardır.

Aşırı iş yükü, iş tatmini ve işten ayrılma niyeti. Bireyin kapasitesi üstünde aşırı iş yükünün, çalışanların iş tatmin düzeyini azaltan psikolojik problemlere sebebiyet verdiği varsayılmaktadır (Qureshi vd., 2012). Bazı görgül çalışmalarda da rasyonel olmayan iş yükünün çalışan memnuniyetini düşürdüğünü ortaya koymaktadır (Keser, 2006; Jones, Chonko, Rangarajan \& Roberts, 2007; Gökkaya, 2014; Pradana \& Salehudin, 2015). Bu kapsamda aşağıdaki hipotez önerilmiştir.

Hipotez 2: Aşırı iş yükü algılarının iş tatmin düzeyleri üzerinde anlamlı etkisi vardır.

İş tatmini, çalışanların gerekli iş görevlerini iyi bir performans ile icrasını sağlayan çalışan eğilimlerini yönlendirir, sonrasında ise davranışlarını etkiler. İşlerinden memnun olan çalışanların pozitif çalışan davranışlarında bulunabileceği ifade edilebilir (Arnett, Laverie \& McLane, 2002). Öte yandan örgütten beklenen fayda ile gerçekleşen fayda arasındaki farkın yüksekliği örgütten ayrılma eğiliminin temel belirleyicisi olabilmektedir (Saeed, Waseem, Sikander \& Rizwan, 2014). Bu bağlamda aşağıdaki hipotez geliştirilmiştir.

Hipotez 3: $\dot{I}_{\text {ş }}$ tatmininin işten ayrlma niyeti üzerinde anlamll etkisi vardır. 
Aşırı iş yükünün işten ayrılma niyetini aynı yönde yordaması, iş tatmininin ise işten ayrılma niyetini aksi yönde etkiliyor olması, aşırı iş yükü ile işten ayrılma niyeti arasındaki nedensellik ilişkisinde iş tatmininin aracı bir rol oynayabileceğini akla getirmektedir. Örneklemde bu rolü test etmek üzere aşağıdaki araştırma hipotezi önerilmiştir.

Hipotez 4: Aşırı iş yükünün işten ayrılma niyetine etkisinde iş tatmininin aracılık rolü vardır.

Aşırı iş yükü, kişi-örgüt uyumu ve işten ayrılma niyeti. Aşırı iş yükü algısının, bireylerin ve örgütlerin değerleri, ihtiyaçları ve çıkarları arasındaki ahenke (Judge \& Bretz, 1992) zarar verdiği saptanmıștır. $\mathrm{Bu}$ kapsamda aşağıdaki hipotez önerilmiştir.

Hipotez 5: Aşırı iş yükü algılarının kişi-örgüt uyumu üzerinde anlamll etkisi vardır.

Kişinin sahip olduğu değerler ile örgütsel değerler arasındaki uyum seviyesinin düşüklüğü ise tatminsizlik ve işten ayrılma eğilimi ile ziyadesiyle ilişkili görünmektedir (Lovelace \& Rosen, 1996). Bu nedenle aşağıdaki hipotez geliştirilmiştir.

Hipotez 6: Kiși-örgüt uyumunun ișten ayrlma niyeti üzerinde anlamll etkisi vardır.

İşten ayrılma niyetinin hem aşırı iş yükü hem de kişi-örgüt uyumu ile ilişkisinden hareketle aşırı iş yükünün kişi örgüt uyumu üzerinden işten ayrılma niyetini etkilemesi beklenmektedir. $\mathrm{Bu}$ bağlamda aşağıdaki araştırma hipotezi önerilmiştir.
Hipotez 7: Aşırı iş yükünün işten ayrılma eğilimine etkisinde kişi-örgüt uyumunun aracılık rolü vardır.

Aşırı iş yükü, iş tatmini, kişi-örgüt uyumu ve işten ayrılma niyeti. Aşırı iş yükünün işten ayrılma niyeti üzerindeki etkisinde iş tatmini ve kişi-örgüt uyumu ayrı ayrı aracılık yapabileceği gibi ikisinin birden aracılık rolü oynaması da beklenmektedir. Çalışmada bunu test etmek üzere aşağıdaki hipotez önerilmiştir.

Hipotez 8: Aşırı iş yükünün işten ayrllma eğilimine etkisinde hem iş tatmininin hem de kişi-örgüt uyumunun aracılık rolü vardır.

\section{YÖNTEM}

\subsection{Araştırmanın Amacı}

Araştırmanın temel amacı kamu güvenliğinden sorumlu çalışanların aşırı iş yükü, iş tatmini, kişiörgüt uyumu ve işten ayrılma niyeti düzeyini ve bu değişkenlerin birbirleri ile olan ilişkilerini inceleyerek, iş tatmini ve kişi-örgüt uyumunun, aşırı iş yükü ile işten ayrılma niyeti ilişkisi üzerindeki aracılık rolünü analiz etmektir.

\subsection{Araștırmanın Modeli}

Yukarıda geliştirilen araştırma hipotezlerine göre tasarlanmış araştırma modeli Şekil 1'de sunulmuştur.

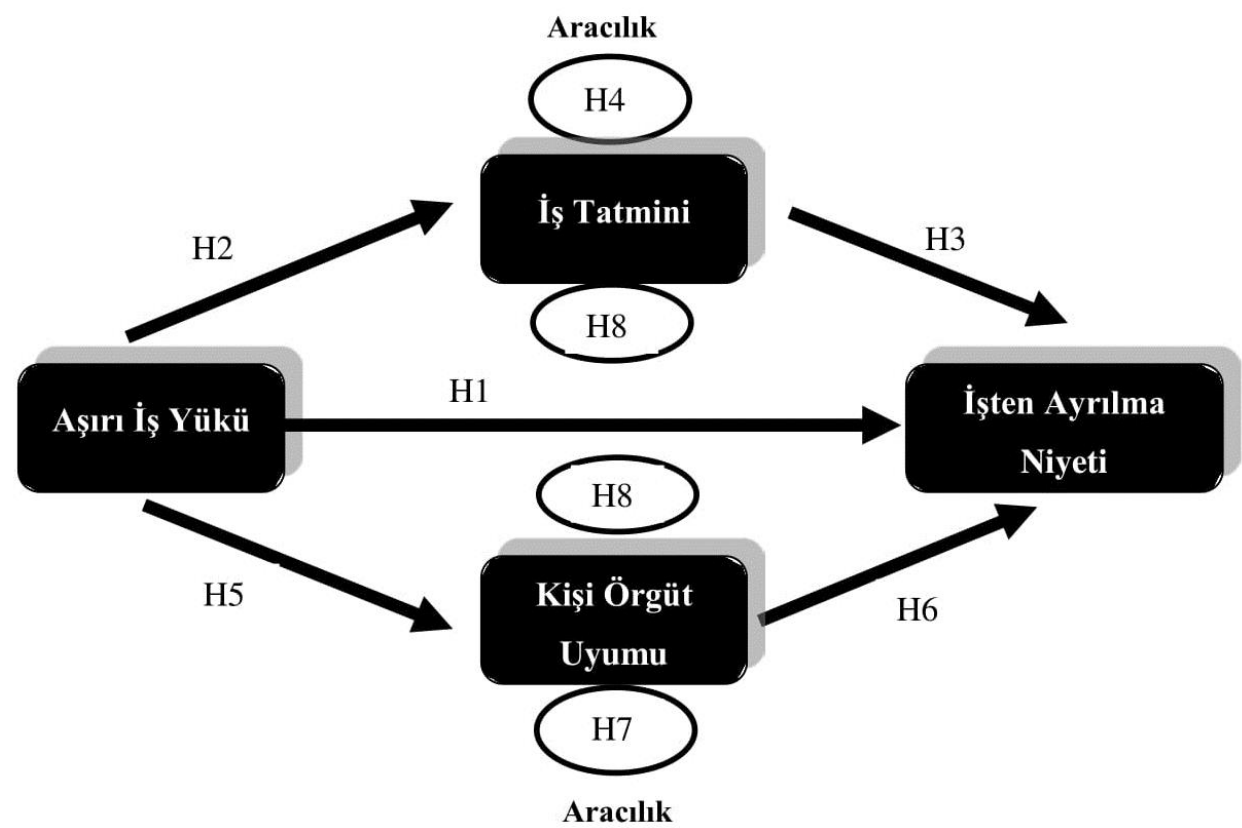

Șekil 1: Araștırmanın Modeli 


\subsection{Araştırmanın Yöntemi}

Araştırmada çalışanlardan anket yöntemi ile veriler toplanmıştır. Elde edilen verileri analiz etmek üzere tek yönlü varyans (ANOVA), korelasyon ve hiyerarşik regresyon analizleri ile yapısal eşitlik modellemesinden faydalanılmıştır.

\subsection{Araştırmanın Evreni ve Örneklemi}

Araştırmanın evreni ulusal düzeyde güvenlikten sorumlu kamu örgütünde sözleşmeli olarak çalışanlardır. Bu örgütte sözleşmeli olarak Şubat 2020 ayı itibariyle 109.067 çalışan istihdam edilmektedir. Araştırmanın örneklemini ise evreni temsil edecek nitelikte söz konusu kamu kuruluşunun Kayseri ve Bolu illerinde konuşlu birimlerinde sözleşmeli olarak çalışanlar içerisinden kolayda örnekleme yöntemi ile seçilen 581 katılımcı oluşturmaktadır.

\section{5. Ölçüm Araçları}

Anket formu iki bölüm ve toplam 25 maddeden oluşmaktadır. Birinci bölümde katılımcının yaşı, mesleki tecrübesi, eğitim düzeyi ve operasyon temposu demografik değişkenleri yer almaktadır. İkinci bölümde, işten ayrılma niyeti, aşırı iş yükü, iş tatmini ve kişi-örgüt uyumu ile ilgili sorular bulunmaktadır. Araştırmada ölçüm araçları demografik değişkenler dişında, 5'li Likert ölçeği ile değerlendirilmiştir (1=Kesinlikle katılmıyorum, $5=$ Kesinlikle katıliyorum).

İşten Ayrılma Niyeti Ölçeği. Çalışanların işten ayrılma eğilimi Tak ve Çiftçioğlu (2008) tarafindan oluşturulan, Polat (2009) tarafindan geçerlemesi yapılan ölçek ile değerlendirilmiştir (Tak \& Çiftçioğlu, 2008; Polat, 2009). İşten Ayrılma Niyeti Ölçeği 5 maddeden (Örn: Önümüzdeki yıllarda başka bir işyerinde çalışmayı düşünüyorum) oluşmaktadır ve 2 madde ters kodlanmıştır. Araştırma kapsamında ölçeğin güvenirlik katsayısı ( $\alpha$ ) 0.80 olarak hesaplanmıştır.

Aşırı Işs Yükü Ölçeği. Çalışanların aşırı iş yükü algısını ölçmek için Peterson, Smith, Akande ve Ayestaran (1995) tarafindan geliştirilen, Derya (2008) tarafından Türkçe'ye uyarlanan aşırı iş yükü ölçeği kullanılmıştır (Peterson, Smith, Akande \& Ayestaran, 1995; Derya, 2008). Mevcut çalışmada ölçeğin tek boyutlu yapısı doğrulayıcı faktör analizi ile doğrulanamamıştır. Yapılan keşfedici faktör analizinde zihinsel iş yükü (Örn: Yaptığım iş bilgi ve beceri seviyemin üzerinde) ve fiziksel iş yükü (Örn: İşim hafta sonları ve akşamları da çalışmamı gerektiriyor) olmak üzere iki alt boyut oluşmuştur. Mevcut çalışmada güvenirlik katsayıları fiziksel iş yükü boyutu için 0.76 , zihinsel iş yükü boyutu için 0.77 olarak bulunmuştur.

İş Tatmini Ölçeği Çalışanların genel iş tatmini düzeyleri Hackman ve Oldham (1974) tarafından geliştirilen, Basım ve Şeşen (2009) tarafından Türkçe'ye uyarlanan bir ölçek ile değerlendirilmiştir (Hackman \& Oldham, 1974; Basım \& Şeşen, 2009). Ölçek 5 maddeden (Örn: İşimden çok keyif alıyorum) oluşmaktadır. Çalışmada ölçeğin güvenirlik katsayısı 0.82 olarak tespit edilmiştir.

Kişi-Örgüt Uyumu Ölçeği. Çalışanların kişi-örgüt uyumu algılamaları Netemeyer, Boles, McKee ve McMurrian (1997) tarafından geliştirilen, Elçi, Alpkan ve Çekmecelioğlu (2008) tarafından Türkçe'ye uyarlanan ölçek ile ölçümlenmiştir (Netemeyer, Boles, McKee \& McMurrian, 1997; Elçi, Alpkan \& Çekmecelioğlu, 2008). Ölçek 4 maddeden (Örn: Çalıştı̆̆ım kurumun insanlara bakışıyla ilgili değerleri ile kişisel değerlerim aynıdır) oluşmaktadır. Çalışmada ölçeğin güvenirlik katsayısı 0.79 olarak hesaplanmıştır.

\subsection{Geçerlilik Analizleri}

Çalışmada, ölçeklerin örnekleme uygunluğu ve yapı geçerliğini sınamak üzere doğrulayıcı faktör analizi yapılmıştır. Ölçeklere ait uyum iyiliği ölçüm değerleri Tablo 1'de sunulmuştur. Uyum iyiliği değerleri, önerilen modellerin elde edilen veriyi iyi açıklayıp açıklamadığının göstergeleridir ( $\mathrm{Hu} \&$ Bentler, 1999). Bu endekslerden Uyum İyiliği İndeksi (GFI) 0.85'den büyük, Düzeltilmiş Uyum İyiliği İndeksi (AGFI) 0.80'den büyük ve Karşılaştırmalı Uyum İyiliği İndeksi (CFI) ise 0.90'dan büyük olması gerekmektedir. Yaklaşık Hataların Ortalama Kare Kökü (RMSEA) ve Standartlaştırılmış Ortalama Hataların Karekökü (SRMR) için 0.08 ve altındaki değerler kabul edilebilir uyum değerinin göstergesidir (Hu \& Bentler, 1999; Raykov \& Marcoulides, 2006). Aşırı iş yükü ölçeği 2 faktörlü, diğer ölçekler 1 faktörlü ve uyum iyiliği değerlerinin kabul edilebilir aralıkta olduğu saptanmıştır. Dolayısıyla araştırmada kullanılan ölçeklerin örneklem için geçerli olduğu tespit edilmiştir. 
Tablo 1: Ölçeklerin Doğrulayıcı Faktör Analizi Sonuçları

\begin{tabular}{lcccccccc}
\hline Model & $\chi \mathbf{2}$ & sd & $\chi \mathbf{2} / \mathbf{s d}$ & GFI & AGFI & SRMR & CFI & RMSEA \\
\hline $\begin{array}{l}\text { İșten Ayrilma Niyeti } \\
\text { (Tek faktörlü) }\end{array}$ & 8.71 & 3 & 2.903 & 0.994 & 0.970 & 0.022 & 0.994 & 0.057 \\
\hline $\begin{array}{l}\text { Așirı İş Yükü } \\
\text { (İki faktörlü) }\end{array}$ & 178.582 & 40 & 4.465 & 0.949 & 0.917 & 0.057 & 0.927 & 0.077 \\
\hline $\begin{array}{l}\text { İş Tatmini } \\
\text { (Tek faktörlü) }\end{array}$ & 9.143 & 5 & 1.829 & 0.994 & 0.982 & 0.022 & 0.996 & 0.038 \\
\hline $\begin{array}{l}\text { Kişi-Örgüt Uyumu } \\
\text { (Tek faktörlü) }\end{array}$ & 0,061 & 1 & 0,061 & 1.000 & 0.999 & 0.002 & 1.000 & 0.000 \\
\hline
\end{tabular}

\section{BULGULAR}

\subsection{Demografik Özellikler}

Katılımcıların demografik özellikleri Tablo 2'de gösterilmektedir.

\subsection{Farklılık Analizleri}

Demografik faktörlerin, araştırma değişkenlerini farklılaştırıp farklılaştırmadığını ortaya koymak maksadıyla yapılan tek yönlü varyans analizi (ANOVA) sonucunda yaş ve eğitim düzeyine göre araştırma değişkenleri anlamlı olarak farklılaşmamaktadır. Mesleki tecrübeye göre iş tatmini düzeyleri 1 yıldan az olanların 1-2 y1l olanlara göre anlamlı bir şekilde düşmekte, kişiörgüt uyumuna göre örgütte 1 y1ldan az ve 1-2 y1l arası mesleki tecrübeye sahip çalışanlar arasında, çalışma süresi arttıkça kişi-örgüt uyumunda anlamlı şekilde azalış meydana geldiği tespit edilmiştir. Ayrıca örgütte 1 yıldan az mesleki tecrübeye sahip bireylerden mesleki tecrübesi 1-2 yıl aras1, 2-4 yıl arası ve 4 yıldan fazla olanlara gidildikçe işten ayrılma eğilimlerinde anlamlı bir artış tespit edilmiştir. Son olarak operasyon temposuna göre örneklemin büyük çoğunluğunu ihtiva eden ve eğitim süreci devam ettiği için operasyona hiç çıkmamış bireylere nazaran 1-10 arası ve 11-50 arası operasyona çıkan bireylerin işten ayrılma eğilimlerinin anlamlı bir şekilde artış gösterdiği saptanmıştır.

\subsection{Değişkenler Arasındaki İlişkiler}

Değişkenlerin ortalama, standart sapma ve korelasyon değerleri Tablo 3'de gösterilmektedir. Fiziksel iş yükü ile zihinsel iş yükü $(r=0.89$, $\mathrm{p}<0.01)$ ve işten ayrılma niyeti arasında $(\mathrm{r}=0.43$, $\mathrm{p}<0.01$ ) anlamlı ve aynı yönde, fiziksel iş yükü ile iş tatmini $(\mathrm{r}=-0.32, \mathrm{p}<0.01)$ ve kişi-örgüt uyumu $(\mathrm{r}=-0.30, \mathrm{p}<0.01)$ arasında ise anlamlı ve aksi yönde bir ilişki saptanmıştır.

Zihinsel iş yükü ile iş tatmini $(r=-0.37, \mathrm{p}<0.01)$ ve kişi-örgüt uyumu $(\mathrm{r}=-0.34, \mathrm{p}<0.01)$ arasında fiziksel iş yüküne benzer anlamlı ve aksi yönde bir ilişki var iken işten ayrılma niyeti ile arasında aynı yönde bir ilişki $(\mathrm{r}=0.44, \mathrm{p}<0.01)$ tespit edilmiştir. İş tatmini ile kişi-örgüt uyumu arasında $(\mathrm{r}=0.59, \mathrm{p}<0.01)$ anlamlı ve aynı yönde, işten ayrılma niyeti ile $(\mathrm{r}=-0.71$, $\mathrm{p}<0.01$ ) anlamlı ve aksi yönde bir ilişki bulgusuna ulaşılmıştır. Son olarak kişi-örgüt uyumu ile işten ayrılma niyeti arasında ise anlamlı ve aksi yönde bir ilişki $(\mathrm{r}=-0.30, \mathrm{p}<0.01)$ saptanmıştır.

\subsection{Regresyon Analizi Bulguları}

Aşırı iş yükü iki boyutta değerlendirildiğinden iki ayrı hiyerarşik regresyon analizi yapılmıştır. Birinci ve ikinci aşama analiz sonuçları Tablo 4 ve Tablo 5 'te sunulmuştur.

Her iki regresyon analizi incelendiğinde hem fiziksel iş yükünün $(\mathrm{B}=0.24)$, hem de zihinsel iş yükünün $(\mathrm{B}=0.40)$ işten ayrılma niyetini anlamlı bir şekilde yordadığı saptanmıştır, dolayısıyla Hipotez 1 desteklenmiştir. Fiziksel iş yükü $(B=-0.40)$ ve zihinsel iş yükü $(\mathrm{B}=-0.88)$ iş tatminini aksi yönde etkilemek suretiyle Hipotez 2 de desteklenmiştir. İş tatmini $(B=-0.46)$ işten ayrılma niyetini anlamlı ve aksi yönde etkileyerek Hipotez 3 kabul edilmiştir. Fiziksel iş yükü $(\mathrm{B}=-0.15)$ ve zihinsel iş yükü $(\mathrm{B}=$ 0.32 ) kişi-örgüt uyumunu aksi yönde etkilemek suretiyle Hipotez 5, kişi-örgüt uyumu da $(B=-0.24)$ işten ayrilma niyetini aksi yönde yordayarak Hipotez 6 desteklenmiştir 


\subsection{Aracılık Analizi Bulguları}

Değişkenler arası ilişkilerdeki aracılık rolleri SPSS 15 programı üzerinde çalışan PROCESS v2.16 (Hayes, 2018) eklentisi kullanılarak hesaplanmıştır. Aracilık etkilerinin istatistiksel olarak anlamlı olup olmadığını görmek üzere dolaylı etkiler, önyüklemeli yanlılığı düzeltilmiş \% 95 güven aralığ1 yöntemiyle (Shrout \& Bolger, 2002; Preacher \& Hayes, 2008) incelenmiștir. Önyükleme örneklemi 5000 olarak belirlenmiştir. Elde edilen fiziksel iş yükünün işten ayrılma niyeti üzerindeki etkisinde aracılık analizi sonuçları Tablo 6'da, zihinsel iş yükünün işten ayrılma niyeti üzerindeki aracılık analizi sonuçları ise Tablo 7'de belirtilmiștir. Sonuçlar incelendiğinde fiziksel iş yükünün $(\mathrm{B}=0.19,0.14<\mathrm{YD} \% 95 \mathrm{GA}>0.25)$ ve zihinsel iş yükünün $(\mathrm{B}=0.41,0.31<\mathrm{YD} \% 95 \mathrm{GA}>$ $0.52)$ iş tatmini üzerinden işten ayrılma niyetindeki dolaylı etkisinin anlamlı olduğu bulunmuştur. 
Tablo 4: Birinci Aşama Regresyon Analizi Sonuçları

\begin{tabular}{lccc}
\hline & \multicolumn{3}{c}{ Bağımlı Değişken } \\
Bağımsız Değişkenler & İş Tatmini & Kişi-Örgüt Uyumu & İşten Ayrılma Niyeti \\
\cline { 2 - 4 } & Model 1 & Model 2 & Model 3 \\
& $\mathbf{B}$ & $\mathbf{B}$ & $\mathbf{B}$ \\
\hline Sabit & $\mathbf{3 . 4 4 1 * *}$ & 0.345 & $\mathbf{2 . 9 5} * *$ \\
Yaş & 0.005 & 0.036 & -0.007 \\
Mesleki Tecrübe & -0.005 & -0.025 & 0.026 \\
Operasyon Temposu & -0.045 & -0.089 & $\mathbf{0 . 0 7 5 *}$ \\
Fiziksel İş Yükü & $\mathbf{0 . 4 0 * *}$ & $\mathbf{- 0 . 1 5 * *}$ & $\mathbf{0 . 2 4} * *$ \\
İş Tatmini & - & $\mathbf{0 . 5 3} 3^{* *}$ & $\mathbf{- 0 . 4 6 * *}$ \\
Kişi-Örgüt Uyumu & - & - & $\mathbf{- 0 . 2 4 * *}$ \\
$\mathbf{R}^{2}$ & $\mathbf{0 . 1 0 4}$ & $\mathbf{0 . 3 7 2}$ & $\mathbf{0 . 6 0 6}$ \\
\hline
\end{tabular}

$* * p<.001,{ }^{*} p<.05$

Tablo 5: İkinci Așama Regresyon Analizi Sonuçları

\begin{tabular}{|c|c|c|c|}
\hline \multirow{4}{*}{ Bağımsız Değişkenler } & \multicolumn{3}{|c|}{ Bağımlı Değişken } \\
\hline & İş Tatmini & Kişi-Örgüt Uyumu & İşten Ayrılma Niyeti \\
\hline & Model 1 & Model 2 & Model 3 \\
\hline & B & B & B \\
\hline Sabit & $3.626 * *$ & 0.439 & $3.058 * *$ \\
\hline Yaş & -0.003 & 0.033 & -0.005 \\
\hline Mesleki Tecrübe & 0.007 & -0.020 & 0.022 \\
\hline Operasyon Temposu & -0.072 & $-0.100 *$ & $0.087 *$ \\
\hline Zihinsel İş Yükü & $-0.884 * *$ & $-0.326^{* *}$ & $0.403 * *$ \\
\hline İş Tatmini & - & $0.515^{* *}$ & $-0.464 * *$ \\
\hline Kişi-Örgüt Uyumu & - & - & $-0.245 * *$ \\
\hline $\mathbf{R}^{2}$ & 0.144 & 0.376 & 0.598 \\
\hline
\end{tabular}

${ }^{*} p<<.001,{ }^{*} p<.05$ 
Dolaysıyla Hipotez 4 desteklenmiştir. Benzer şekilde fiziksel iş yükünün $(\mathrm{B}=0.04,0.02<\mathrm{YD}$ $\% 95 \mathrm{GA}>0.06)$ ve zihinsel iş yükünün $(\mathrm{B}=0.08$, $0.04<$ YD \%95 GA> 0.13) kişi-örgüt uyumu üzerinden işten ayrılma niyetindeki dolaylı etkisinin anlamlı olduğu tespit edilmiş ve Hipotez 7 kabul edilmiştir. Son olarak fiziksel iş yükünün $(B=0.05$,
$0.03<\mathrm{YD} \% 95 \mathrm{GA}>0.08)$ ve zihinsel iş yükünün $(\mathrm{B}=0.11,0.08<\mathrm{YD} \% 95 \mathrm{GA}>0.16)$ iş tatmini ve kişi-örgüt uyumu üzerinden işten ayrılma niyetindeki dolaylı etkisinin anlamlı olduğu saptanmıştır. $\mathrm{Bu}$ kapsamda Hipotez 8 desteklenmiştir.

Tablo 6: Fiziksel İş Yükünün İşten Ayrılma Niyeti Üzerindeki Etkisinde Aracılık Analizi Sonuçları

\begin{tabular}{|c|c|c|c|c|}
\hline \multirow[b]{2}{*}{ İncelenen Etki } & \multirow[b]{2}{*}{ B } & \multirow[b]{2}{*}{ S.H. } & \multicolumn{2}{|c|}{$\begin{array}{c}\text { Önyükleme YD } \\
\% 95 \text { GA }\end{array}$} \\
\hline & & & Alt Sinır & Üst Sınır \\
\hline \multicolumn{5}{|l|}{ Fiziksel İş Yükü - $\rightarrow$ İşten Ayrılma Niyeti } \\
\hline Doğrudan Etki & 0.240 & 0.033 & 0.1754 & 0.3062 \\
\hline Dolaylı Etki (Aracı: İş Tatmini) & 0.189 & 0.027 & 0.1381 & 0.2468 \\
\hline \multicolumn{5}{|l|}{ Fiziksel İş Yükü - $\rightarrow$ İşten Ayrılma Niyeti } \\
\hline Doğrudan Etki & 0.240 & 0.033 & 0.1754 & 0.3062 \\
\hline Dolaylı Etki (Aracı: Kişi-Örgüt Uyumu) & 0.036 & 0.012 & 0.0150 & 0.0638 \\
\hline \multicolumn{5}{|l|}{ Fiziksel İş Yükü - $\rightarrow$ İşten Ayrılma Niyeti } \\
\hline Doğrudan Etki & 0.240 & 0.033 & 0.1754 & 0.3062 \\
\hline $\begin{array}{l}\text { Dolaylı Etki } \\
\text { (Aracılar: İș Tatmini } \rightarrow \text { Kişi Örgüt Uyumu) }\end{array}$ & 0.052 & 0.010 & 0.0341 & 0.0777 \\
\hline
\end{tabular}

Tablo 7: Zihinsel İş Yükünün İşten Ayrılma Niyeti Üzerindeki Etkisinde Aracılık Analizi Sonuçları

\begin{tabular}{|c|c|c|c|c|}
\hline \multirow[b]{2}{*}{ İncelenen Etki } & \multirow[b]{2}{*}{$\mathbf{B}$} & \multirow[b]{2}{*}{ S.H. } & \multicolumn{2}{|c|}{$\begin{array}{c}\text { Önyükleme YD } \\
\% 95 \text { GA }\end{array}$} \\
\hline & & & Alt Sinur & Üst Sınır \\
\hline \multicolumn{5}{|l|}{ Zihinsel İş Yükü - $\rightarrow$ İşten Ayrılma Niyeti } \\
\hline Doğrudan Etki & 0.403 & 0.064 & 0.2776 & 0.5293 \\
\hline Dolaylı Etki (Aracı: İş Tatmini) & 0.410 & 0.053 & 0.3101 & 0.5215 \\
\hline \multicolumn{5}{|l|}{ Zihinsel İş Yükü - $\rightarrow$ İşten Ayrılma Niyeti } \\
\hline Doğrudan Etki & 0.403 & 0.064 & 0.2776 & 0.5293 \\
\hline Dolaylı Etki (Aracı: Kişi-Örgüt Uyumu) & 0.080 & 0.023 & 0.0388 & 0.1315 \\
\hline \multicolumn{5}{|l|}{ Zihinsel İş Yükü - $\rightarrow$ İşten Ayrılma Niyeti } \\
\hline Doğrudan Etki & 0.403 & 0.064 & 0.2776 & 0.5293 \\
\hline $\begin{array}{l}\text { Dolaylı Etki } \\
\text { (Aracılar: İş Tatmini } \rightarrow \text { Kişi Örgüt Uyumu) }\end{array}$ & 0.111 & 0.021 & 0.0756 & 0.1603 \\
\hline
\end{tabular}




\section{SONUC, TARTISMA VE ÖNERILER}

Çalışmada aşırı iş yükü algılarının işten ayrılma niyeti üzerindeki etkisi ve aşırı iş yükü ile işten ayrılma niyeti ilişkisinde iş tatmininin ve kişi-örgüt uyumunun aracılık rolü ulusal düzeyde güvenlikten sorumlu çalışanlar örnekleminde incelenmiştir. Bulgulara bakıldığında aşırı iş yükünün işten ayrılma niyetini anlamlı bir şekilde artırdığı görülmüştür. Bu sonuçtan çalışanların kapasitesinin üzerinde ve sınırlı bir sürede bitirilmesi gerekli çok sayıda görevler atanması halinde bireyin işten ayrılma eğilimi sergileyebileceği anlaşılmaktadır.

Söz konusu sonuçlar, Iverson ve Deery'nin (1997) 246 otel çalışanın iştirakiyle yaptığı çalışma, Brannon, Barry, Kemper, Schreiner ve Vasey'in (2007) 3039 sosyal hizmet çalışanı üzerinde yaptığı çalışma ve Zeytinoğlu vd. (2007) 3 hastanede görevli 1396 hemşire üzerinde yaptığı çalışmanın sonuçlarını destekler niteliktedir (Iverson \& Deery, 1997; Zeytinoğlu vd., 2007; Brannon vd., 2007).

İs tatmini ve kiși-örgüt uyumunun ise ișten ayrılma niyetini aksi yönde etkilediği tespit edilmiştir. $\mathrm{Bu}$ bulgu iş tatmininin işten ayrılma niyetinin önemli belirleyicilerinden olduğu bilgisini (Saeed vd., 2014; Lam, Baum, \& Pine, 2001; Amah, 2009; Lu, Lin, Wu, Hsieh, \& Chang, 2002; Başak, Ekmekçi, Bayram, \& Baş, 2013) teyit etmektedir. Ayrıca bireyin ihtiyaçlarının örgüt tarafından karşılanması halinde ortaya çıkan olumlu tutumlar, güçlükleri hafifletebilir, daha yüksek performansı kolaylaştırabilir ve işten ayrılmayı azaltabilir (Kristof-Brown, Zimmerman, \& Johnson, 2005).

Son olarak çalışmada aşırı iş yükünün bireylerin iş tatmini düzeylerini azaltıp, sonrasında kişi-örgüt uyumunu zayiflatmak suretiyle işten ayrılma eğilimini artırdığı saptanmıştır. Bu sonuç, aşırı iş yükünün işten ayrılma niyetini neden ve nasıl etkilediği konusunda iş tatmini ve kişi-örgüt uyumunun sahip olduğu potansiyeli ortaya koymak suretiyle örgütsel davranış ve insan kaynakları yönetimi alanlarına önemli bir katkı sunmaktadır.

İşten ayrılma eğilimi örgüt için arzu edilmeyen bir değişken olmasına rağmen örgütsel verimlilik üzerindeki olumsuz etkisini en aza indirmek için onun tetikleyicilerini anlamak kıymetlidir (Kim, Leong, \& Lee, 2005). Bilgi, beceri ve yeteneğinin üstünde bireyden beklenen taleplerin, tatminsizlik ve değer uyumu düşüklüğüne sebebiyet verdiği gerçeğinden hareketle çalışan iş yüklerinin sürekli gözetlenmesi örgüte fayda sağlayabilecektir.

Aşırı iş yükünün iş tatmini ve kişi-örgüt uyumu üzerinden işten ayrılma niyetindeki dolaylı etkilerinden hareketle, yöneticilerin çalışanlara tatminkâr bir iş ortamı sağlamak suretiyle tatmin düzeyinin yükseltilmesi ve kariyer planlamaları, eğitimler ile değer uyumunun artırılması sayesinde kalifiye çalışanları örgütte muhafaza etme konusunda proaktif davranış sergilemesi mümkün olabilecektir.

Sonuçların tutarlı olup olmadığını görmek için gelecekteki çalışmaların boylamsal veya farklı zamanlarda tekrarlanması önem arz etmektedir. Ayrıca gelecekteki araştırmalarda alternatif iş imkânları, yaşam doyumu ve sürekli değişen durumlara esnek bir şekilde uyum sağlama kapasitesi olarak karakterize edilen, psikolojik sermayenin alt boyutlarından biri olan psikolojik dayanıklılık gibi değişkenlerin işten ayrılma eğilimini etkileme gücünün ortaya çıkarılması faydalı olabilecektir.

İșten ayrılma niyetinin birçok öncülü bulunmasına rağmen bu çalışmada sadece aşırı iş yükü, iş tatmini ve kişi-örgüt uyumu etkileri üzerine odaklanılmıştır. İşten ayrılma niyetinin yordayıcısı olabilecek diğer faktörlerin araştırma kapsamına alınmamış olması bir sınırlılık olarak görülebilir. Ölçekler bireylerin öznel algılamalarını değerlendirdiğinden çalışanların ideal durumları yansıtan algılarını işaretleyebileceği, dolayısıyla sosyal beğenirlik etkisi ve ortak yöntem varyansı olabileceği sonuçlar değerlendirilirken dikkate alınmalıdır.

\section{ETIKK BEYANATI}

Destek Bilgisi: Bu çalı̧̧ma, kamu, ticari veya kar amacı gütmeyen kuruluşlar gibi herhangi bir organizasyondan destek almamıştır.

Çıkar Çatışması: Sorumlu yazar çıkar çatışması olmadığını belirtir.

Etik Onay: İnsan katılımcıları içeren çalışmalarda gerçekleştirilen tüm prosedürler, kurumsal ve / veya ulusal araştırma komitesinin etik standartlarına ve 1964 Helsinki deklarasyonuna ve daha sonraki değişikliklerine veya karşıış̧ıtırılabilir etik standartlara uygundur.

Bilgilendirilmiş Onam Formu: Çalışmaya katılan tüm bireysel katılımcılardan bilgilendirilmiş onam formu alınmıştır. 


\section{KAYNAKÇA}

Adkins, C. L., Russell, C. J. \& Werbel, J. D. (1994). Judgments of fit in the selection process: The role of work value congruence. Personnel Psychology, 47, 605-623.

Alexander, J. A., Bloom, J. R. \& Nuchols, B. A. (1994). Nursing turnover and hospital efficiency: An organization-level analysis. Industrial Relations, 33, 505-520.

Alnıaçık, E., Alnıaçık, Ü., Erat, S. \& Akçin, K. (2013). Does person-organization fit moderate the effects of affective commitment and job satisfaction on turnover intentions? Procedia-Social and Behavioral Sciences, 99, 274-281.

Amah, O. E. (2009). Job satisfaction and turnover intention relationship: The moderating effect of job role centrality and life satisfaction. Research and Practice in Human Resource Management, 17(1), 2435.

Arnett, D. B., Laverie, D. A. \& McLane, C. (2002). Using job satisfaction and pride as internal-marketing tools. Cornell Hotel and Restaurant Administration Quarterly, 5(2), 87-96.

Aryee, S., Wyatt, T. \& Min, M. K. (1991). Antecedents of organizational commitment and turnover intentions among professional accountants in different employment settings in Singapore. The Journal of Social Psychology, 131, 545-556.

Basım, N. \& Şeşen, H. (2009). Örgütsel adalet algıs1örgütsel vatandaşlık davranışı ilişkisinde iş tatmininin aracılık rolü. 17'nci Yönetim ve Organizasyon Kongresi, 21-23 Mayıs, Eskişehir.

Başak, E., Ekmekçi, E., Bayram, Y. \& Baş, Y. (2013). Analysis of factors that affect the intention to leave of white-collar employees in Turkey using structural equation modelling. Proceedings of the World Congress on Engineering and Computer Science, 2325 October, San Francisco, USA.

Beehr, T. A., Walsh, J. T. \& Taber, T. D. (1976). Relationship of stress to individually and organisationally valued states: Higher order needs as a moderator. Journal of Occupational and Environmental Medicine, 19(11), 771.

Bluedorn, A. C. (1982). A unified model of turnover from organizations. Human Relations, 35, 135-153.

Boxx, R. W., Odom, R. Y. \& Dunn, M. G. (1991). Organizational values and value congruency and their impact on satisfaction, commitment and cohesion: An empirical examination within the public sector. Public Personnel Management, 20(1), 195-206.

Brannon, D., Barry, T., Kemper, P., Schreiner, A. \&
Vasey J. (2007). Job perceptions and intent to leave among direct care workers: Evidence from the better jobs better care demonstrations. The Gerontologist, 47(6), 820-829.

Bretz, R. D. \& Judge, T. A. (1994). Person-organization fit and the theory of work adjustment: Implications for satisfaction, tenure and career success. Journal of Vocational Behavior, 44, 32-54.

Brookfield, H. B. (1998). The impact of flexible benefits plans on job satisfaction, organizational commitment and turnover intention. Benefits Quarterly, 10, 84-90.

Chan, E. Y. \& Morrison, P. (2000). Factors influencing the retention and turnover intentions of registered nurses in a Singapore hospital. Nursing and Health Sciences, 2(2), 113-121.

Chatman, J. A. (1989). Improving interactional organizational research: A model of personorganization fit. Academy of Management Review, 14(3), 333-349.

Chatman, J. A. (1991). Matching people and organizations: Selection and socialization in public accounting firms. Administrative Science Quarterly, $36,459-484$.

Colucia, M. Z. O. \& Alexandrea, N. M. C. (2012). Job factors related to musculoskeletal symptoms among nursing personnel-a review. Work, 41, 2516-2520.

Cordes, C. L. \& Dougherty, T. W. (1993). A review and integration of research on job burnout. Academy of Management Review, 18(4), 621-656.

Cotton, J. L. \& Tuttle, J. M. (1986). Employee turnover: A meta-analysis and review with implications for research. Academy of Management Review, 11(1), 5570.

Coverman, S. (1989). Role overload, role conflict and stress: Addressing consequences of multiple role demands. Social Forces, 67(4), 965-982.

Dalton, D. R., Todor, W. D. \& Krackhardt, D. M. (1982). Turnover overstated: A functional taxonomy. Academy of Management Review, 7, 117-132.

Das, B. L. \& Baruah, M. (2013). Employee retention: A review of literature. IOSR Journal of Business and Management, 14(2), 8-16.

Derya, S. (2008). Crossover of work-family conflict: Antecedent and consequences of crossover process in dual-earner couples (Yayımlanmamış doktora tezi). Sosyal Bilimleri Enstitüsü, İstanbul: Koç Üniversitesi.

Elangovan, A. R. (2001). Causal ordering of stress, satisfaction and commitment and intention to quit: A structural equations analysis. Leadership and Organization Development Journal, 22(4), 159-165. 
Elçi, M., Alpkan, L. \& Çekmecelioğlu, G. H. (2008). The influence of person organization fit on the employee's perception of organizational performance. 4th International Strategic Management Conference, 1921 June, Sarajevo, Bosnia-Herzegovnia.

Firth, L., Mellor, D. J., Moore, K. A. \& Loquet, C. (2004). How can managers reduce employee intention to quit? Journal of Managerial Psychology, 19(2), 170-187.

Fishbein, M. \& Ajzen, I. (1975). Belief, attitude, intention, and behavior: An introduction to theory and research. Reading, MA: Addison-Wesley.

Ghiselli, R., Lopa, J. L. \& Bai, B. (2001). Job satisfaction, life satisfaction and turnover intent of food service managers. Cornell Hotel and Restaurant Administration Quarterly, 42(2), 28-37.

Gökkaya, Ö. (2014). Yerel yönetimlerde iş-yaşam dengesi ve çalışan davranışı ilişkisinin incelenmesiKocaeli belediyeleri örneği. Elektronik Mesleki Gelişim ve Araştırmaları Dergisi, 2, 2-18.

Greenhaus, J. H., Parasuraman S., Granrose, C. S., Rabinowitz, S. \& Beutell N. J. (1989) Sources of work- family conflict among two career couples. Journal of Vocational Behaviour, 34, 133-153.

Griffeth, R. W., Hom, P.W. \& Gaertner, S. (2000). A meta-analysis of antecedents and correlates of employee turnover: Update, moderator tests, and research implications for the millennium. Journal of Management, 26, 463-488.

Hackman, J. R. \& Oldham, G. R. (1974). The job diagnostic survey: An instrument for the diagnosis of jobs and the evaluation of job re-design projects. Technical Report, Department of Administrative Sciences, Yale University.

Hayes, A. F. (2018). Introduction to mediation, moderation, and conditional process analysis: A regression-based perspective (2nd Ed.). New York, NY: The Guilford Press.

Hellman, C. M. (1997). Job satisfaction and intent to leave. The Journal of Social Psychology, 137(6), 677689.

Hom, P.W. \& Griffeth, R.W. (1991). Structural equations modeling test of a turnover theory: Cross-sectional and longitudinal analyses. Journal of Applied Psychology, 76(3), 350-366.

Hu, L. T. \& Bentler, P. M. (1999). Cutoff criteria for fit indexes in covariance structure analysis: Conventional criteria versus new alternatives. Structural Equation Modeling: A Multidisciplinary Journal, 6(1), 1-55.

Ivancevich, J. M. \& Matteson, M. T. (1987).
Organization behavior and management, Plano, Texas, Business Publications.

Iverson, R. D. \& Deery, M. (1997). Turnover culture in the hospitality industry. Human Resource Management Journal, 7(4), 71-82.

Jones, E., Chonko, L., Rangarajan, D. \& Roberts J. (2007). The role of overload on job attitudes, turnover intentions and salesperson performance. Journal of Business Research, 60, 663-671.

Judge, T. A. \& Bretz, R. D. (1992). The effects of values on job choice decisions. Journal of Applied Psychology, 77(3), 261-271.

Judge, T. A. \& Ferris, G. R. (1992). The elusive criterion of fit in human resources staffing decisions. Human Resource Planning, 15(4), 47-67.

Kalliath, T. J. \& Beck, A. (2001). Is the path to burnout and turnover paved by a lack of supervisory support: a structural equations test. New Zealand Journal of Psychology, 30, 72 - 8.

Keser, A. (2006). Çağrı merkezi çalışanlarında iş yükü düzeyi ile iş doyumu ilişkisinin araştırılması. Kocaeli Üniversitesi Sosyal Bilimler Enstitüsü Dergisi, 11(1), 100-119.

Kim, W. G., Leong, J. K. \& Lee, Y. K. (2005). Effect of service orientation on job satisfaction, organizational commitment and intention of leaving in a casual dinning chain restaurant. International Journal of Hospitality Management, 24(2), 171-193.

Koslowsky, M., Sagie, A., Krausz, M. \& Singer, A. D. (1997). Correlates of employee lateness: Some theoretical considerations. Journal of Applied Psychology, 82, 79-88.

Kristof-Brown, A. L. (1996). Person-organization fit: An integrative review of its conceptualizations, measurement and implications. Personnel Psychology, 49(1), 1-49.

Kristof-Brown, A. L., Zimmerman, R. D., \& Johnson, E. C. (2005). Consequences of individuals' fit at work: A meta-analysis of person-job, person-organization, person-group, and person-supervisor fit. Personnel Psychology, 58, 281-342.

Lam, T., Baum, T., \& Pine, R. (2001). Study of managerial job satisfaction in Hong Kong's Chinese restaurants. International Journal of Contemporary Hospitality Management, 13(1), 35-42.

Lam, T., Zhang, H. \& Baum, T. (2001). An investigation of employees' job satisfaction: The case of hotels in Hong Kong. Tourism Management, 22, 157-165.

Landsbergis, P. A. (1988). Occupational stress among health care workers: A test of the Job DemandsControl Model. Journal of Organizational Behavior, 


\section{$9,217-239$}

Lovelace, K. \& Rosen, B. (1996). Differences in achieving person-organization fit among diverse group of managers. Journal of Management, 22(5), 703-722.

Lu, H., Alison E., While, K. \& Barriball, L. (2005). Job satisfaction among nurses: A literature review. International Journal of Nursing Studies, 42, 211227.

Lu, K. Y., Lin, P. L., Wu, C. M., Hsieh, Y. L. \& Chang, Y. Y. (2002).The relationships among turnover intentions, professional commitment and job satisfaction of hospital nurses. Journal of Professional Nursing, 18(4), 214-219.

Maslach, C. \& Leiter, P. M. (1997). The truth about burnout, San Francisco: Jossey-Bass.

McBey, K. \& Karakowsky L. (2001). Examining sources of influence on employee turnover in the part-time work context. Career Development International, 6(1), 39-47.

Mobley, W. H. (1977). Intermediate linkages in the relationship between job satisfaction and employee turnover. Journal of Applied Psychology, 62(2), 237240.

Mobley, W. H., Horner, S. O. \& Hollingsworth, A. T. (1978). An evaluation of precursors of hospital employee turnover. Journal of Applied Psychology, 63(4), 408-414.

Moorman, R. H., Niehoff, B. P., \& Organ, D. W. (1993). Treating employees fairly and organizational citizenship behavior: Sorting the effects of job satisfaction, organizational commitment and procedural justice. Employees Responsibilities and Rights Journal, 6, 209-225.

Morrell, K., Loan-Clarke, J., \& Wilkinson, A. (2001). Unweaving leaving: The use of models in themanagement of turnover. International Journal of Management Reviews, 3(3), 219-244.

Mowday, R. T., Koberg, C. S., \& McArthur, A. W. (1984). The psychology of the withdrawal process: A cross-validational test of Mobley's intermediate linkages model of turnover in two samples. Academy of Management Journal, 27(1), 79-94.

Mowday, R. T., Porter, L. W., \& Steers, R. M. (1982). Organizational linkages: The psychology of commitment, absenteeism, and turnover, San Diego, CA: Academic Press.

Netemeyer, R. G., Boles, J. S., McKee, D. O., \& McMurrian, R. (1997). An Investigation into the Antecedents of Organizational Citizenship Behaviors in a Personal Selling Context. Journal of Marketing, 61, 85-98.
O'Reilly, C. A., Chatman, J. \& Caldwell, D. F. (1991). People and organizational culture: A profile comparison approach to assessing personorganization fit. Academy of Management Journal, 34(3), 487-516.

Peters, L. H., Bhagat, R. S. \& O'Connor, E. J. (1981). An examination of the independent and joint contributions of organizational commitment and job satisfaction on employee intentions to quit. Group and Organization Studies, 6(1), 73-82.

Peterson, M. F., Smith, P. B., Akande, A. \& Ayestaran, S. (1995). Role conflict, ambiguity and overload: A 21nation study. Academy of Management Journal, 38, 429-452.

Pienaar, J., Sieberhagen, C. F. \& Mostert, K. (2007). Investigating turnover intentions by role overload, job satisfaction and social support moderation. $S A$ Journal of Industrial Psychology, 33(2), 62-67.

Polat, M. (2009). Örgütsel özdeşleşmenin öncülleri ve ardılları üzerine bir saha çalışması (Yayımlanmamış doktora tezi). Sosyal Bilimleri Enstitüsü, Bursa: Uludağ Üniversitesi.

Porter, L.W. \& Steers, R. M. (1973). Organizational, work and personal factors in employee turnover and absenteeism. Psychological Bulletin, 80, 151-176.

Pradana, A. \& Salehudin, I. (2015). Work overload and turnover intention of junior auditors in greater Jakarta, Indonesia. The South East Asian Journal of Management, 9(2), 108-124.

Preacher, K. J. \& Hayes, A. F. (2008). Asymptotic and resampling strategies for assessing and comparing indirect effects in multiple mediator models. Behavior Research Methods, 40, 879-891.

Price, J. L. \& Mueller C. W. (1981). A causal model of turnover for nurses. The Academy of Management Journal, 24(3), 543-565.

Qureshi, M. I., Jamil, R. A., Iftikhar, M., Arif, S., Lodhi, S., Naseem, I. \& Zaman, K. (2012). Job stress, workload, environment and employees turnover intentions: Destiny or choice. Archives Des Sciences, 65 (8), 230-241.

Raykov, T. \& Marcoulides, G. A. (2006). A first course in structural equation modeling, 2. Bask1 (pp: 46-48), Mahwah, New Jersey, Lawrence Erlbaum Associates.

Repetti, R. L. (1993). Short-term effects of occupational stressors on daily mood and health complaints. Health Psychology, 12(2), 125-131.

Saeed, I., Waseem, M., Sikander, S. \& Rizwan, M. (2014). The relationship of turnover intention with job satisfaction, job performance, leader member exchange, emotional intelligence and organizational commitment. International Journal of Learning and 
Development, 4(2), 242-256.

Saks, A. M. (1996). The relationship between the amount of helpfulness of entry training and work outcomes. Human Relations, 49, 429 - 51.

Samad, S. (2006). The contribution of demographic variables: job characteristics and job satisfaction on turnover intentions. The Journal of Human Resource and Adult Learning, 1(1), 12-20.

Shaw, J. D., Gupta, N. \& Delery, J. E. (2005). Alternative conceptualizations of the relationship between voluntary turnover and organizational performance. Academy of Management Journal, 48, 50-68.

Shore, L. M. \& Martin, H. J. (1989). Job satisfaction and organizational commitment in relation to work performance and turnover intentions. Human Relations, 42, 625-638.

Shrout, P. E. \& Bolger, N. (2002). Mediation in experimental and nonexperimental studies: New procedures and recommendations. Psychological Methods, 7, 422-445.

Silverthorne, C. (2004). The impact of organizational culture and person-organization fit on organizational commitment and job satisfaction in Taiwan. Leadership and Organization Development Journal, 25, 592-599.

Sims, R. L. \& Kroeck, K. G. (1994). The influence of ethical fit on employee satisfaction, commitment and turnover. Journal of Business Ethics, 13, 939-947.

Sousa-Poza, A. \& Henneberger, F. (2004). Analyzing job mobility with job turnover intentions: An international comparative study. Journal of Economic Issues, 38(1), 113-137.

Spector, P. E., Dwyer, D. J. \& Jex, S. M. (1988). Relation of job stressors to affective, health and performance outcomes: A comparison of multiple data sources. Journal of Applied Psychology, 73, 11-19.

Spector, P. E. \& Jex, S. M. (1998). Development of four self-report measures of job stressors and strain: Interpersonal conflict at work scale, organizational constraints scale, quantitative workload inventory and physical symptoms inventory. Journal of Occupational Health Psychology, 3(4), 356-367.

Steel, R. P., Griffeth, R. W. \& Hom, P. W. (2002). Practical retention policy for the practical manager. Academy of Management Executive, I6(2), 149-162.

Sümer, C. H. \& Van de Ven, C. (2007). Chapter 4B-A proposed model of military turnover. RTO-TR-HFM107, 1-18.

Sverke, M., Hellgren, J. \& Öhrming, J. (1999). Organisational restructuring and health care work: A quasi-experimental study. In PM. le Blanc, Peeters,
MCW, Bussing A ve Schaufeli, WB. (Eds.), Organisational psychology and health care: European contributions (pp. 15-32), Munchen, Germany: Rainier Hampp Verlag.

Tak, B. \& Çiftçioğlu, B. A. (2008). Mesleki bağlılık ile çalışanların örgütte kalma niyeti arasındaki ilişkiyi incelemeye yönelik görgül bir çalışma. Ankara Üniversitesi Siyasal Bilgiler Fakültesi Dergisi, 63(4), 156-178.

Tett, R. P. \& Meyer, J. P. (1993). Job satisfaction, organizational commitment, turnover intention, and turnover: Path analyses based on meta-analytical findings. Personnel Psychology, 46, 259-293.

Van Dyk, J. \& Coetzee, M. (2012). Retention factors in relation to organisational commitment in medical and information technology services. SA Journal of Human Resource Management, 10(2), 433-444.

Vancouver, J. B. \& Schmitt, N. W. (1991). An exploratory examination of person-organization fit: Organizational goal congruence. Personnel Psychology, 44, 333-352.

Westerman, J. W. \& Cyr, L. A. (2004). An integrative analysis of person-organization fit theories. International Journal of Selection and Assessment, 12(3), 252-261.

Xiaoming, Y., Ma, B. J., Chang, C. L. \& Shieh, C. J. (2014). Effects of workload on burnout and turnover intention of medical staff: A study. Studies on Ethno Medicine, 8(3), 229-237.

Yadav, P. \& Aspal, J. (2014). Importance of job satisfaction and talent management. International Journal of Research in IT and Management, 4(7), 5565.

Yücel, İ. (2012). Examining the relationships among job satisfaction, organizational commitment, and turnover intention: An empirical study. International Journal of Business and Management, 7(20), 44-58.

Yücel, İ. \& Demirel, Y. (2013). Mevcut iş alternatiflerinin iş tatmini ve işten ayrılma ilişkisi üzerine etkisi: "Başka bir yol daha olmalı!". Atatürk Üniversitesi İktisadi ve İdari Bilimler Dergisi, 27(2), 159-177.

Zeytinoglu, I. U., Denton, M., Davies, S., Baumann, A., Blythe, J. \& Boos, L. (2007). Deteriorated external work environment, heavy workload and nurses' job satisfaction and turnover intention. Canadian Public Policy/Analyse de Politiques, 33(1), 31-47. 